\title{
Factors Influencing Employee Absenteeism in IT Companies at Trichy
}

\author{
Aishwariyashindhe S, Sathyapriya J, Vijayalakshmi.P.S, Sudha
}

\begin{abstract}
Employees are not present in work and so the work suffers. The researcher focuses to sort the motives for employee's absenteeism in an organization. It is the key problem faced by more or less all the employers nowadays. Absenteeism of employees from job results in backlogs, pile of labour and therefore work delays. The objective of the paper is to identify the predominant factor influencing employee absenteeism and to measure the impact of factors influencing employee absenteeism on employee productivity. Descriptive research design is used for this reseacrh. Data was collected from 150 employees using Convenience sampling technique from the employees of IT companies at Trichy. The data were analyzed using descriptive statistics to identify the predominant factor influencing employee absenteeism and multiple regression to measure the impact of factors influencing employee absenteeism on employee productivity. From the analysis, it was found that stress at the workplace is the predominant factor highly influencing employee absenteeism. It was also found that improper time management is highly influencing employee absenteeism factor on employee productivity.
\end{abstract}

Index Terms: Employee absenteeism, Employee productivity, IT companies, Multiple regression.

\section{INTRODUCTION}

When employees are absent to do their scheduled job is highly known to be employee absenteeism. Silpa (2015) argued that employee absenteeism is one of the severe workplace issues which because expensive for both employers and employees. Vijaya and Sheela (2012) stated that lack of training, quality of work life, policies regarding promotion; incentives are the factors contributing to employee absenteeism. It not only affects the labour but also its economy, in relation with that of the other factors. Cascio (2003) defined absence as the breakdown of an worker to the description designed for or stay behind at job as programmed, in spite of of the cause, articulates a monitory suggestion. The term as scheduled is very important, calculated used for this normally prohibits vacations, holidays, jury duty, etc., It also eradicates the important trouble whether the absence is allowable or not. Tiwari (2014) defined absence as the nonexistence of staff from usual work lacking earlier consent. Extreme absence involve an extensive defeat to the venture since work planned are distress and overdue along with organization has to offer eventually wages to complete within

Aishwaryashindhe S, Department of Management Studies, Periyar Maniammai Institute of Science \& Technology, Thanajvur, India.

Sathyapriya J, Department of Management Studies, Periyar Maniammai Institute of Science \& Technology, Thanjavur, India.

Vijayalakshmi.P.S, Department of Business Economics, Ethiraj College for Women, Chennai, India.

Sudha, Department of Business Economics, Ethiraj College for Women, Chennai, India.
Revised Manuscript Received on July 22, 2019

the release dates. The overtime wage rates are twice than the usual wage rates. Adegboyega, Olawumi Dele and Michael Ayodeji (2015) found member of staff inspiration, shift system, teamwork and other ways of improving worker cheerfulness and job satisfaction have been practiced by management to condense employee absenteeism and labour turnover to recover overall organizational performance. Vijaya Bhaskar Reddy, Vez and et al., (2014) found that employee absenteeism is a key trouble faced by more or less all employers nowadays. Employees abstain from work and as a result, the work suffers. Absence of employees from work directs to support logs, piling of work and thus work impediments. Absenteeism in the workplace has talented reasons, with sickness being the input one. But then not each and every one illness absenteeism is attributable to illness. Absenteeism is not a reasonable absence that is excused by the employer or the result of legal medical condition or disability. Both valid absences and absenteeism can impact the organization, but perceptive which the first step is towards nullifying their property. Absenteeism is the term given when an employee is usually and regularly not present from work. This exclude rewarded run off with occasion where an boss have arranged an worker time off.

\section{REVIEW OF LITERATURE}

Cote and Bruce (2004) analyzed the downsize by means of spirited outsourcing: its impact on absence in the public sector in the U.S. Air force association. The main objective of this research was determining whether there was statistically more or less absence in the form of go away being taken in an organization under a study than one not under a competitive sourcing study. The study adopted quantitative analysis. It was found that there is the possibility that employee in the competitive sourcing study organization does not want to bring negative dishonor upon themselves necessity their effort division in the organization actually be outsourced.

Jussi vahtera, Mika kivimaki, and et al., (2004) analyzed the organizational downsizing, sickness absence, and mortality: 10- town potential army study in Finland. The employees include male and female in public workers of Finland. The main objective of this research was to observe whether downsizing, decreasing of workers in organizations, is a forecaster of amplified sickness, deficiency, and mortality among workers. The total participants of this study were male 5909 and female 16521 both municipal employees. The employees belonged to 20-62 years age in their jobs. The main outcome of this research was annual sickness absence rate based on the employer's documentation pre and post downsizing by employment contract; all-cause and specific 
mortality obtained from the national mortality record. It was found that organizational downsizing possibly will amplify sickness, deficiency and the risk of death from heart disease in employees.

Revathi Arunachalamurthy (2014) explored about absenteeism among the employees employed in the manufacturing unit in Coimbatore. The employee includes individual professional career and psychological well-being. The main objective was to find out the rate of absenteeism prevailing in the manufacturing industry. Descriptive research design was adopted. 150 samples were chosen using nonprobability sampling technique. Percentage analysis and chi-squared analysis was used to analyze the primary data. It was found that employee's morale towards the organization is closely associated with the absenteeism. It was recommended that the management can take the necessary steps to reduce absenteeism by implementing the suggestions and execute the schemes by considering the causes of absenteeism.

Don - Solomon Amakiri and Godday Raymond Luke (2015) found that the job design and employee absenteeism: A case study of some government parastatals in Nigeria. The sample comprises of 348 workers from nineteen different ministries. The main objective of this research was to analyse the relationship between job enlargement and employee absenteeism. The study adopted a descriptive research design. Correlation and coefficient analysis were used to analyze the data. It was found that organizations including ministries be supposed to take a conscious effort in conniving job of its worker taking into concern job enlargement and job rotation, as they are essential ingredients that improve worker attendance rate thus restrains their absenteeism rate.

Shikka Verma and Chaubey (2016) attempted to identify the factors that leads to employee absenteeism and it's effect on occupational stress and job satisfaction: An empirical study in public and private sector. The employees include staff members in public and private sector organizations of Dehradun. The main purpose of this research was to discover not in the stage of work-related pressure surrounded by the employees in the association crossways dissimilar era group. The researcher adopted a descriptive research design. 100 samples were chosen using nonprobability sampling technique. Percentage analysis, one way ANOVA, factor analysis and correlation using SPSS 18.0 were used to analyze the primary data. It was found that observe, evaluate and attempt to recover absence can be particularly hard but with the appropriate sympathetic of what causes absence can be extremely difficult, but with them and how to diminish it the compact can edge the unenthusiastic slide effects of employee attendance issue. As well, absence is absolutely connected with job disappointment, which is related to earnings, which means that the additional an worker miss job, the additional probable he or she is to ultimately go away the organization.

\section{RESEARCH METHODOLOGY}

\section{A. Research Design}

Descriptive Research Design was used for this paper. The research was conducted in IT companies at Trichy. The sample size was 150 . Convenience sampling technique was adopted to collate data using a structured questionnaire.
Descriptive statistics and multiple regression were used for analysing and the results were presented.

\section{B. Research Objectives}

- To identify the predominant factor influencing employee absenteeism

- To measure the impact of factor influencing employee absenteeism on employee productivity

\section{RESUltS AND DisCUSSION}

\section{A. Descriptive Statistics}

\begin{tabular}{|c|c|}
\hline Variables & Mean value \\
\hline Stress at the workplace & 4.62 \\
\hline Excessive workload & 4.19 \\
\hline Role ambiguity & 4.22 \\
\hline Poor supervision & 4.22 \\
\hline Poor physical fitness & 3.93 \\
\hline Inadequate leadership & 3.89 \\
\hline Personal problem & 4.01 \\
\hline Transportation problem & 3.80 \\
\hline Poor working conditions & 3.82 \\
\hline Low-level wages & 3.47 \\
\hline Inadequate facilities & 3.41 \\
\hline Nature of work & 4.33 \\
\hline Unforeseen cause & 4.17 \\
\hline Religious and local festivals & 4.23 \\
\hline Lack of strict code of conduct & 3.91 \\
\hline Sickness & 3.98 \\
\hline Industrial fatigue & 3.68 \\
\hline Unsound personal policies & 3.27 \\
\hline Lack of motivation & 4.44 \\
\hline Poor employee-employer relationship & 3.94 \\
\hline The attitude of the supervisor & 3.99 \\
\hline
\end{tabular}

From the results, the predominant factor influencing employee absenteeism is stress at the workplace. The other factors like excessive workload, role ambiguity, personal problem, poor supervision, inadequate leadership, poor physical fitness, transportation problem, poor working conditions, low level of wages, inadequate facilities, nature of work, unforeseen cause, religious and local festivals, lack of strict code of conduct, sickness, industrial fatigue, unsound personal policies, lack of motivation, poor employee-employer relationship and the attitude of the supervisor have moderate influence on employee absenteeism. 


\section{B. Impact of factors influencing employee absenteeism on employee productivity}

$\mathbf{H}_{\mathbf{0}}$ : There exists no impact on factors influencing employee absenteeism on employee productivity.

$\mathbf{H}_{1}$ : There exists impact on factors influencing employee absenteeism on employee productivity.

Table 4.2: Model Summary

\begin{tabular}{|c|c|c|c|c|}
\hline Model & R & $\begin{array}{c}\text { R } \\
\text { Square }\end{array}$ & $\begin{array}{c}\text { Adjusted R } \\
\text { Square }\end{array}$ & $\begin{array}{c}\text { Std. Error } \\
\text { of the } \\
\text { Estimate }\end{array}$ \\
\hline 1 & $0.834^{\mathrm{a}}$ & 0.695 & 0.667 & 0.304 \\
\hline
\end{tabular}

a. Predictors: (Constant), Attitude of the employee,

Downsizing, Organisational culture, Job design,

Outsourcing, Workload, Skill and traits, Employee health, Improper time management, Availability of tools and equipment

b. Dependent Variable: Employee absenteeism

From table 4.2, R-value of 0.834 indicate a high-quality level of forecast. "R Square" column represent the $R^{2}$ value, which is the percentage of difference in the dependent variable Employee Absenteeism to be capable of be clarify by the independent variable Demographic variable. The $R^{2}$ value is 0.695 that means independent variables clarify $69.5 \%$ of the variableness of the dependent variable Employee Absenteeism.

\begin{tabular}{|l|l|l|c|c|c|c|}
\hline \multicolumn{7}{|c|}{ Table 4.3: ANOVA } \\
\hline \multirow{2}{*}{ Model } & $\begin{array}{c}\text { Sum of } \\
\text { Squares }\end{array}$ & df & $\begin{array}{c}\text { Mean } \\
\text { Square }\end{array}$ & F & Sig. \\
\hline \multirow{2}{*}{1} & Regression & 22.926 & 10 & 2.293 & 24.827 & $.000^{\mathrm{a}}$ \\
\cline { 2 - 7 } & Residual & 10.065 & 109 & 0.092 & & \\
\cline { 2 - 7 } & Total & 32.992 & 119 & & & \\
\hline
\end{tabular}

a. Predictors: Attitude of the employee, Downsizing, Organisational culture, Job design, Outsourcing, Workload, Skill and traits, Employee health, Improper time management, Availability of tools and equipment b. Dependent Variable: Employee absenteeism

The above table 4.3, explains that the independent variables statistically significantly predict the dependent variable, $F$ $(10,109)=24.827, p<.0005$ which shows that the regression model is a good fit.

\begin{tabular}{|c|c|c|c|c|c|}
\hline \multicolumn{6}{|c|}{ Table 4.4: Coefficients } \\
\hline \multirow{2}{*}{ Model } & \multicolumn{2}{|c|}{$\begin{array}{l}\text { Unstandardized } \\
\text { Coefficients }\end{array}$} & \multirow{2}{*}{$\begin{array}{c}\begin{array}{c}\text { Standard } \\
\text { ized } \\
\text { Coefficie } \\
\text { nts }\end{array} \\
\text { Beta } \\
\end{array}$} & \multirow{2}{*}{$\mathbf{t}$} & \multirow{2}{*}{ Sig. } \\
\hline & B & $\begin{array}{c}\text { Std. } \\
\text { Erro } \\
\text { r }\end{array}$ & & & \\
\hline (Constant) & -1.858 & 2.710 & & -.686 & .000 \\
\hline $\begin{array}{l}\text { Attitude of the } \\
\text { employee }\end{array}$ & .211 & .167 & .106 & 1.259 & .211 \\
\hline Downsizing & -1.380 & .565 & -.727 & -2.442 & .000 \\
\hline $\begin{array}{l}\text { Organisational } \\
\text { culture }\end{array}$ & .357 & .227 & .212 & 1.571 & .119 \\
\hline Job design & 1.370 & .114 & .888 & 12.012 & .000 \\
\hline Outsourcing & .564 & .165 & .311 & 3.414 & .000 \\
\hline Workload & -.924 & .147 & -.965 & -6.267 & .000 \\
\hline $\begin{array}{l}\text { Skills and } \\
\text { traits }\end{array}$ & .733 & .225 & .449 & 3.252 & .000 \\
\hline $\begin{array}{l}\text { Employee } \\
\text { health }\end{array}$ & -.557 & .178 & -.352 & -3.128 & .000 \\
\hline $\begin{array}{l}\text { Improper time } \\
\text { management }\end{array}$ & 1.001 & .300 & 1.136 & 3.336 & .000 \\
\hline $\begin{array}{l}\text { Availability of } \\
\text { tools and } \\
\text { equipment }\end{array}$ & -.012 & .066 & -.010 & -.184 & .854 \\
\hline
\end{tabular}

b. Dependent Variable: Employee absenteeism

From the table 4.4, explains unstandardized coefficients which indicate how much the dependent variable (Employee Absenteeism) varies with an independent variable (Demographic variable) when all other independent variables (Attitude of the employee, Downsizing, Organisational culture, Job design, Outsourcing, Workload, Skills and traits, Employee health, Improper time management, Availability of tools and equipment) are held constant. A p value of attitude of the employee, organizational culture and availability of tools and equipment are $0.211,0.119 \& 0.854$. $\mathrm{P}$ value is > 0.05 and hence rejects the null hypothesis. The attitude of the employee, organizational culture and availability of tools and equipment well-being don't have an impact on employee absenteeism.

Multiple Regression equation is:

Employee Absenteeism $=-0.807+(-.1380 *$ Downsizing $)+$ $(1.370 *$ Job design $)-(0.564 *$ Outsourcing $)+(-0.924 *$ Work load $)+(0.733 *$ Skills and traits $)+(-0.557 *$ Employee health $)+(1.001 *$ Improper time management $)$. 
Downsizing, Job design, Outsourcing, Workload, Skills and traits, Employee health, Improper time management significant value is $<0.05$. Hence the accept the alternative hypothesis and it's clear that Attitude of the employee, Downsizing, Organisational culture, Job design, Outsourcing, Workload, Skills and traits, Employee health, Improper time management, Availability of tools and equipment influence Employee Absenteeism.

The Beta value indicates the order of importance of the independent variables. The variable with the highest Beta value is the relatively most important independent variable. On scrutinizing the independent variables in the model, it was found that improper time management made the biggest contribution with the value of 1.136 . It was followed by the Job design (Beta=0.888), Skills and traits (Beta=0.449), Outsourcing $\quad($ Beta=0.311), Organisational culture (Beta=0.212), and Attitude of the employee (Beta=0.106). Although the contribution made by the independent variables such as Improper time management, Workload, Downsizing, Employee health and Availability of tools and equipment were significant, they were found to make the smallest contributions to the model with their determination coefficients of $-.965,-.727,-.352,-.010$ and 1.136, respectively.

\section{CONCLUSION}

Employee Absenteeism results in decreasing the growth of the organization. This study has undertaken different analysis to find factors influencing employee absenteeism. From the analysis, it was found that stress at workplace, excessive workload, poor physical fitness, transportation problem, poor working conditions, unforeseen cause, sickness, lack of motivation, poor employee-employer relationship and the attitude of the supervisor are highly influencing factors to take leave from their job and some of the least reasons are unsound personal policies, industrial fatigue, and poor supervision. It is clear that employees need some interesting facts in the organization to reduce absenteeism. The employer must focus on taking the required steps towards it.

\section{REFERENCES}

1. Cote and Bruce.'Downsizing with competitive outsourcing: its impact on absenteeism in the public sector", VIESOJI POLITIKA IR ADMINISTRAVIMAS, 2004.

2. Jussi vahtera, Mika kivimaki, et al., "Organizational downsizing, sickness absence, and mortality: a 10-towns prospective cohort study". BMJ (online), 2004.

3. Tai tang and Hua Chang, "Impact of role ambiguity and role conflict on employee creativity", African Journal of business management (4) 6 869-881, 2010.

4. Vijaya Bhaskar Reddy, Vez, and et al., "A study on training need assessment in TASA foods private limited, Chittoor," International Journal of researchers students and academician (IFRSA) 2(5)275-280, 2012.

5. Vijaya and Sheela, "A study on worker absence in Sundaram brake linings ltd., Chennai," AMET International journal of management 68-74, 2012.

6. Revathi Arunachalamurthy, "A study on absenteeism among the employees working in the manufacturing unit in Coimbatore," International Journal of science and engineering research (2) 12, 2014

7. Tiwari," Impact of absenteeism and labor turnover on organizational performance at ITI, Nani, Allahabad, India," Abhinav publication 3(10) 9-15, 2014.

8. Don - Solomon Amakiri and Godday Raymond Luke, "Job style and worker absenteeism: A case study of some government parastatals in
Nigeria," International Journal of secondary education, (3) 6-1, 67-71, 2015.

9. Silpa, "A study on symptoms and preventions of employee absenteeism, International journal of scientific and research publications 5(6), 2015.

10. Shikka Verma and Chaubey, "Identifying the factors leading to workplace absenteeism and its effects on occupational stress and job satisfaction: An empirical study", International Journal of organizational behavior and management perspectives (5) 2 2340-2345, 2016 